\title{
Sodium channel blocking (SCB) activity and transformation of paralytic shellfish toxins (PST) by dinoflagellate-associated bacteria
}

\author{
Elizabeth A. Smith*, Fiona H. Mackintosh, Faye Grant, Susan Gallacher \\ Fisheries Research Services, Marine Laboratory, PO Box 101, Victoria Road, Aberdeen AB11 9DB, Scotland, UK
}

\begin{abstract}
Bacteria associated with toxic algae in culture have been implicated in the enhancement of algal toxin production and in auto-toxigenesis, with taxon specificity of the bacteria suggested to be important in their association with the algae. In this study, bacteria isolated from toxic and nontoxic dinoflagellates have been examined for both their potential to produce sodium channel blocking (SCB) toxins, as ascertained by the mouse neuroblastoma assay, and their ability to biotransform paralytic shellfish toxins (PST) using high-performance liquid chromatography (HPLC). Toxigenic bacteria were found to belong to the $\alpha$ - and $\gamma$-Proteobacteria. Bacteria capable of SCB activity were present in PST-producing Alexandrium tamarense and A. lusitanicum cultures, while the bacterial flora isolated from a non-toxic A. tamarense strain did not appear to demonstrate this trait. A disparate population of the bacterial flora associated with non-PST-producing Scrippsiella trochoidea also demonstrated SCB activity. Some bacteria from all the dinoflagellates examined were capable of transforming PST, with possible mechanisms including oxidase activity with transformation of gonyautoxins GTX 2/3 to GTX 1/4, reductive elimination as demonstrated by the transformation of GTX 1/4 to GTX 2/3, and further unknown pathways. Noticeably, there was little overlap between bacteria demonstrating SCB activity and those that were able to modify PST, indicating that biosynthesis of SCB toxins and catabolism of PST may not be related in these bacterial isolates.
\end{abstract}

KEY WORDS: Dinoflagellates $\cdot$ Bacteria $\cdot$ Sodium channel blocking toxins $\cdot$ Mouse neuroblastoma assay $\cdot$ Paralytic shellfish toxins $\cdot \mathrm{HPLC} \cdot$ Biotransformations

\section{INTRODUCTION}

It has been suggested that in some toxic algal cultures both intracellular and free-living bacteria are either directly or indirectly associated with phycotoxin production, although to date no clear picture has emerged (Kodama et al. 1988, Kodama 1990, Danzter \& Levin 1997, Doucette \& Powell 1998). Questions of how or why either organism produces these toxins have also not been fully answered. A key issue for several researchers has been the autonomous bacterial production of paralytic shellfish toxins (PST) (see Gal-

*E-mail: smithe@marlab.ac.uk lacher \& Smith 1999), which in humans can cause severe poisoning via the consumption of contaminated shellfish, which filter-feed on algae, and hence may ingest toxic dinoflagellates (Hall et al. 1990).

Mechanisms of toxin dynamics in bacterial-algal interactions have been largely neglected. Early studies claimed that bacteria from toxic dinoflagellates could confer toxicity to non-toxic algae species and attributed this to the presence of intracellular bacteria (Silva 1982). In some cases taxon specificity has been demonstrated to be important to the association of toxigenic bacteria with toxic algae. For example, Doucette \& Powell (1998) reported that Alexandrium lusitanicum produced less toxin when the bacterial flora was removed, but that toxin levels could be restored upon 
addition of a bacterium considered to be a PST producer and an original member of the dinoflagellate's bacterial consortium. Addition of bacteria alien to the algae did not, however, produce any change in toxicity.

Evidence for bacterial production of PST has mainly been based on the chromatographic behaviour of these compounds and their sodium channel blocking (SCB) activity (Gallacher \& Smith 1999). Nevertheless, important steps in confirming synthesis of PST by bacteria have been made using capillary electrophoresismass spectrometry (Gallacher et al. 1997).

Bacterial biotransformations of PST are another potential mechanism by which these organisms may influence dinoflagellate toxicity. PST consist of saxitoxin (STX) and at least 22 derivatives (e.g. carbamate toxins including STX, neosaxitoxin (NEO) and the gonyautoxins [GTX 1, 2, 3 and 4], $N$-sulfocarbomoyl toxins consisting of GTX 5 and $\mathrm{C}$ toxins and decarbomyl toxins (dcGTX 2 and 3). Each derivative has its own potency, with some being more toxic than others (Shimizu 1993). Early reports by Kotaki et al. (1985a,b) demonstrated that marine bacteria were capable of inter-converting these neurotoxins, and more recently it has been demonstrated that bacteria isolated from a variety of shellfish possess the capacity to carry out side chain modifications of PST (Smith et al. 2001).

Previous phylogenetic analysis of cultivable bacteria associated with PST-producing dinoflagellates (Alexandrium lusitanicum NEPCC 253, A. tamarense NEPCC 407) and non-toxic dinoflagellates ( $A$. tamarense PCC 173, Scrippsiella trochoidea NEPCC 15) placed these bacteria into 25 phyletic groups. These were limited to 2 bacterial phyla, the Proteobacteria ( $\alpha$ - and $\gamma$-) and Cytophaga-Flavobacter-Bacteroides (CFB) (Hold et al. 2001). In this study, selected bacterial isolates from each phyletic group have been assessed for their ability both to produce SCB toxins and to biotransform a range of PST analogues. SCB activity of the bacteria was determined using the mouse neuroblastoma assay (Gallacher et al. 1997), while bacteria were incubated with various toxin analogues and the resulting derivative(s) detected by high-performance liquid chromatography (HPLC) to establish their capacity to transform PST.

\section{MATERIALS AND METHODS}

Bacterial cultures. Bacteria used in this investigation were first isolated from PST-producing Alexandrium lusitanicum NEPCC 253 (= A. minutum), a toxic and non-toxic strain of A. tamarense (NEPCC 407 and PCC 173, respectively) and non-toxic Scrippsiella trochoidea NEPCC 15 by Hold et al. (2001). The bacteria were isolated over the growth cycle of the dinoflagellates in batch culture (early and late exponential and stationary phases) and characterised by sequence determination of their16S rRNA gene (Hold et al. 2001). The bacterial strains used in this study are given in Table 1. All isolates were stored in marine broth (Difco) plus $10 \%$ glycerol at $-70^{\circ} \mathrm{C}$ prior to investigation.

Detection of SCB activity using the mouse neuroblastoma (MNB) assay. Bacterial strains were cultured for $18 \mathrm{~h}$ in $30 \mathrm{ml}$ of marine broth $\left(20^{\circ} \mathrm{C} ; 120\right.$ oscillations $\mathrm{min}^{-1}$ ). Supernatants and cells were separated by centrifugation at $10000 \times g$ for $20 \mathrm{~min}$. Supernatant $(20 \mathrm{ml})$ from each isolate was stored at $4^{\circ} \mathrm{C}$ until processed by the MNB assay as previously detailed (Gallacher et al. 1997).

HPLC analysis of PST transformations. A mixture of $24 \mathrm{~h}$ bacterial cultures grown in marine broth (196 $\mu \mathrm{l})$ and individual toxin standards $(4 \mu \mathrm{l})$ were incubated in an orbital shaker $\left(20^{\circ} \mathrm{C}_{i} 120\right.$ oscillations $\left.\mathrm{min}^{-1}\right)$ for 0 , $12,24,48$ and $72 \mathrm{~h}$. Final concentrations of the individual toxins were $\left(\mathrm{ng}^{-1} \mathrm{l}^{-1}\right)$ : GTX 1, 1.48; GTX 4, 0.64;

Table 1. Dinoflagellate-associated bacterial strains. ${ }^{*}$ Bacterial isolates were obtained from: ALUS_253, Alexandrium lusitanicum NEPCC 253; ATAM_407, A. tamarense NEPCC 407; ATAM173a, A. tamarense PCC 173; SCRIPPS, Scrippsiella trochoidea NEPCC 15

\begin{tabular}{|ll|}
\hline Bacterial isolate & GenBank accession no. \\
\hline $\boldsymbol{\alpha}$-Proteobacteria & \\
ALUS253_18 (= ATAM407_61) & AF359525 \\
ALUS253_59 (= ALUS253_43) & AF359526 \\
ATAM407_2983 (= ATAM407_62) & AF359529 \\
SCRIPPS_732 & AF359534 \\
ATAM407_2976 (= ATAM407_56) & AF359535 \\
ATAM173a_51 & AF359538 \\
ATAM173a_9 & AF359544 \\
ALUS253_27 (= ALUS253_28 & AF359524 \\
ALUS253_25 & AF359524 \\
ATAM407_68 & AF359528 \\
SCRIPPS_101 & AF359537 \\
SCRIPPS_738 (=SCRIPPS_94) & AF359545 \\
SCRIPPS_739 & AF359546 \\
SCRIPPS_423 & AF359547 \\
SCRIPPS_426 & AF359549 \\
SCRIPPS_733 & Not fully sequenced \\
$\boldsymbol{\gamma}$-Proteobacteria & \\
SCRIPPS_740 & AF359550 \\
ATAM407_77 (= ATAM407_18) & AF359529 \\
ATAM173a_5 & AF359542 \\
ATAM173a_36 & AF359543 \\
ATAM407_2035 & AF359552 \\
Cytophaga-Flavobacter-Bacteroides \\
ATAM173a_3 & AF359540 \\
SCRIPPS_413 & AF359548 \\
ATAM173a_6 & AF359541 \\
ALUS253_6 & AF359551 \\
\hline
\end{tabular}


GTX 2, 2.40; GTX 3, 0.58; GTX 5, 2.22; STX, 2.80; NEO, 2.80. A sample (2 $\mu$ l) of each culture was spread onto marine agar after $72 \mathrm{~h}$ to ensure that cultures were still viable. Controls sampled over the same time period consisted of toxin standards in marine broth in the absence of bacteria. Controls and spent media from the bacterial cultures were subsequently analysed for residual substrates and their products by HPLC, applying the isocratic methods of Franco \& Fernández-Vila (1993), with modifications detailed in Smith et al. (2001).

\section{RESULTS AND DISCUSSION}

\section{Production of SCB toxins}

The MNB assay used in this study to ascertain whether bacteria were toxigenic is highly specific for SCB toxins and is based on the pharmacological actions of these compounds (Gallacher \& Birkbeck 1992). However, although highly sensitive, it does not differentiate which of the spectra of PST is present. Nor does it distinguish PST from another group of SCB toxins, the tetrodotoxins, which are widely accepted as being produced by bacteria (Matsui et al. 1989, Gallacher \& Birkbeck 1992, Lee et al. 2000). Nevertheless, the MNB assay has been used to infer PST toxicity in marine bacteria by a number of researchers (see Doucette et al. 1998, Gallacher \& Smith 1999). Hence, while the evidence for PST production by bacteria is compelling, in the absence of confirmatory mass spec- trometric data bacteria in this study giving a positive result by the MBA are currently only considered to produce SCB toxins.

Seven out of the 25 bacterial strains investigated in this study were found to produce SCB toxins when grown in marine broth (Table 2). Of these toxigenic bacteria, ALUS253_59 and ATAM407_2976 were closely related with the Roseobacter phylogenetic lineage within the $\alpha$ subclass of the Proteobacteria. Strain ATAM407_2976 demonstrates greater than 99\% 16S rRNA sequence homology with bacterial isolate $667-2$, which was previously isolated from a weakly toxic culture of Alexandrium affine (Hold et al. 2001) and is reported as capable of synthesising multiple PST derivatives (Gallacher et al. 1997). It is interesting to note that Rausch de Traubenberg (1993), Lafay et al. (1995), Prokic et al. (1998), Alavi et al. (2001) and Vásquez et al. (2001) have all isolated and characterised bacteria as belonging to the Roseobacter clade (including the Sulfitobacter genera) from dinoflagellate cultures. Although the bacteria isolated by Prokic et al. (1998) were not found to be toxic per se, Rausch de Traubenberg (1993) suggested that strains of Roseobacter algicola (= Ruegeria algicola) synthesise the phycotoxin okadaic acid, and Vásquez et al. (2001) reported SCB activity in a Sulfitobacter strain.

Other bacteria within the $\alpha$-Proteobacteria demonstrating SCB activity were ALUS253_25, SCRIPPS_423, SCRIPPS_426 and SCRIPPS_733 (Table 2). Isolate ALUS253_25 is closely associated with the PTB strains (Groben et al. 2000, Hold et al. 2001). These strains include PTB1, originally isolated from a highly toxic

Table 2. Dinoflagellate-associated bacteria demonstrating sodium channel blocking (SCB) activity.

\begin{tabular}{|c|c|c|c|}
\hline $\begin{array}{l}\text { Bacterial } \\
\text { isolate }\end{array}$ & $\begin{array}{l}\text { SCB activity } \\
\text { activity (nM) }\end{array}$ & $\begin{array}{l}\text { Nearest neighbour } \\
\text { (GenBank accession no.) }\end{array}$ & $\begin{array}{l}\text { 16S rRNA sequence } \\
\text { similarity }(\%)^{\mathrm{a}}\end{array}$ \\
\hline \multicolumn{4}{|c|}{$\alpha$-Proteobacteria (Roseobacter clade) } \\
\hline ALUS253_59 & 35 & Roseovarius tolerans (Y11551) & 99.6 \\
\hline ATAM407_2976 & 34 & $\begin{array}{l}\text { Roseobacter gallaeciensis (Y13244) } \\
\text { Isol. 667-2 (AJ294353) isolated from }\end{array}$ & 98.9 \\
\hline & & Alexandrium affine NEPCC 667 & 99.9 \\
\hline \multicolumn{4}{|l|}{$\alpha$-Proteobacteria } \\
\hline ALUS253_25 & 39 & $\begin{array}{l}\text { Stappia stellulata (D88525) } \\
\text { Isol. PTB1 (Y10913) isolated from highly } \\
\text { toxic Japanese Alexandrium tamarense } \\
\text { Clone isol. PTB5 (AJ000646) }\end{array}$ & $\begin{array}{l}98.6 \\
99.7 \\
99.4\end{array}$ \\
\hline SCRIPPS_423 & 64 & Hyphomonnas oceanitis (AF082797) & 90.9 \\
\hline SCRIPPS_426 & 39 & Caulobacter vibroides (AJ227754) & 94.5 \\
\hline SCRIPPS_733 & 72 & Unknown (not fully sequenced) & - \\
\hline $\begin{array}{l}\boldsymbol{\gamma} \text {-Proteobacteria } \\
\text { ATAM407_77 }\end{array}$ & 84 & $\begin{array}{l}\text { Alteromonas macleodii (X82145) } \\
\text { Isol. 407-2 (AJ294360), 2c3 (AJ294361), } \\
\text { 253-19 (AJ294362) isolated from toxic } \\
\text { Alexandrium sp. cultures }\end{array}$ & $\begin{array}{l}98.9 \\
98.3\end{array}$ \\
\hline
\end{tabular}


Alexandrium tamarense clone (Ogata et al. 1990, Kopp et al. 1997) and reported to be capable of producing PST as defined by HPLC (Doucette \& Trick 1995). It is thought that further strains within the same bacterial lineage may differ in their abilities to produce such toxins. For example, PTB 6 isolated from a weakly toxic $A$. tamarense culture is reported to be capable of PST production, while PTB 7 isolated from a non-toxic $A$. tamarense culture does not appear to demonstrate this function (Doucette \& Trick 1995). SCRIPPS_423 and SCRIPPS_426 are distantly related to the Hyphomonas and Caulobacter genera respectively (Hold et al. 2001). To our knowledge this is this first case of SCB activity being observed in such bacteria.

Within the $\gamma$-Proteobacteria, SCB toxicity was only detected in strain ATAM407_77, which is closely related to Altermonas macleodii (Hold et al. 2001). Other toxin-producing bacteria within this genus include the phylogenetically characterised bacteria 407-2, 2c3 and 253-19 isolated from toxic Alexandrium spp. (Gallacher et al. 1997, Hold et al. 2001) and 6SMI isolated from seawater and identified using carbon utilisation profiles (Levasseur et al. 1996). Within the $\gamma$-Proteobacteria, other bacteria reported to show SCB activity include Acinetobacter and Pseudomonas spp. (Levasseur et al. 1996), and bacteria isolated from shellfish by Juntongjin et al. $(1993,1996)$ and identified using $\mathrm{G}+\mathrm{C}$ DNA content as belonging to the Vibrio and Pseudomonas genera. Franca et al. (1996) also reported that Pseudomonas spp. produce PST. However, in this study strain SCRIPPS_740 is known to be closely related to Pseudomonas stutzeri (Hold et al. 2001) and did not demonstrate SCB toxin production. All 4 strains tested within the CFB phyla were negative for SCB activity, even though SCB activity has previously been reported in a Flavobacterium sp. (Juntongjin et al. 1996).

From this and previous studies it would appear that several closely related bacteria originating from dinoflagellate cultures and distinctly different marine environments have the ability to synthesise SCB toxins. SCB toxin production by bacteria appears to span across species in different phylogenetic lineages, suggesting that this property is not uncommon among marine bacteria. However, direct association of these bacteria with eukaryotic organisms does not appear to be a prerequisite for toxin production. These observations pose the question of the possible function of such toxins in bacteria. PST have variously been linked to ideas of chemical defence in order to protect an environmental niche, to provide nitrogen reserves, to act in cell signalling or to aid osmotic regulation (Gallacher et al. 1997, Cembella 1998, Johnston et al. in press). However, PST have not been directly linked to these by any mechanistic evidence and the metabolic functions of the SCB toxins detected in this study, the reasons for their production, and their physiological and ecological significance remain unresolved.

Bacteria-producing SCB compounds were isolated from Alexandrium tamarense NEPCC 407 and A. lusitanicum at all growth phases examined, suggesting that toxigenic bacteria may contribute to PST levels in these cultures. Interestingly, bacteria isolated from non-toxic A. tamarense PCC 173 did not demonstrate SCB activity under the conditions used in this investigation. Toxigenic bacteria were, however, isolated from non-PST-producing Scrippsiella trochoidea, raising questions on the identity of the SCB compounds being produced and highlighting that further detailed spectral analysis is required to more clearly define the SCB compounds produced by these bacteria. The toxigenic bacterial strains isolated from $S$. trochoidea were not closely related with SCB-active bacteria isolated from the toxic Alexandrium cultures (Hold et al. 2001). What may be of interest, therefore, are possible bacterial species-specific associations with harmful algal species in nature. Future investigations in this area may contribute to our understanding of variations in the toxicity of individual algae.

\section{PST biotransformations by dinoflagellate-associated bacteria}

Studies conducted by Kotaki (1989), Kotaki et al. (1985a,b) and more recently by Smith et al. (2001) suggested that bacterial isolates from shellfish were capable of transforming PST. Bacterial transformations of PST are further potential mechanisms by which these organisms may influence dinoflagellate and shellfish toxicity. Therefore, this study further aimed to determine if PST could be utilised and/or modified by the algal-associated bacteria. With this aim, the bacteria were incubated with PST standards in marine broth and toxin profiles monitored over time using HPLC. As such, 5 out of the 25 bacterial strains investigated were found to transform PST (Table 3).

Quantitative assessment of control samples containing marine broth and PST standards (GTX 1/4, GTX 2/3 and GTX 5) but no bacteria showed that at least $98 \%$ of these toxins were recovered at all the time points investigated (Fig. 1). STX and NEO were also completely recovered from the marine broth in control samples. When the bacterial strains were grown with the addition of STX and NEO, reduction in the concentration of these toxins was again not observed throughout the incubation period (data not shown). It was previously reported that bacteria associated with shellfish were unable to transform or utilise these PST analogues under similar growth conditions (Smith et al. 2001). 


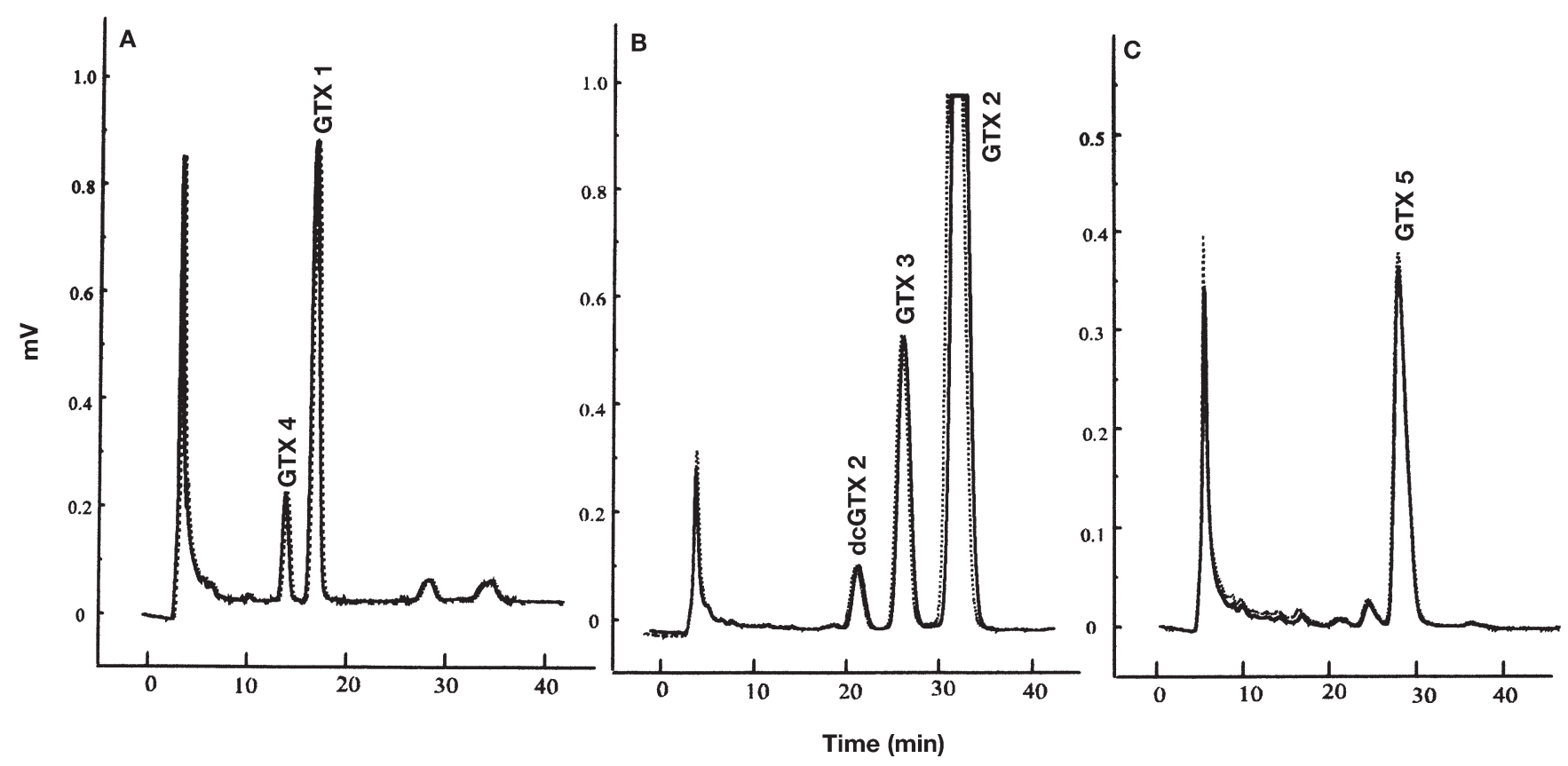

Fig. 1. Chromatogram showing paralytic shellfish toxin (PST) standards in marine broth: Marine broth spiked with (A) GTX 1/4; (B) GTX2/3; (C) GTX 5. Samples shown were taken at $0 \mathrm{~h}$ (black line) and $72 \mathrm{~h}$ (dotted line)

HPLC analysis of bacterial supernatants grown with GTX standards showed that bacterial strains within the $\alpha$-Proteobacteria were capable of utilising and/or transforming these toxins (Table 3, Figs. 2, $3 \& 4$ ). As with the SCB-active bacteria, PST-transforming bacteria were found to be associated with both toxic and non-toxic dinoflagellates throughout the dinoflagellates' growth phase. Predominantly, of the isolates examined, the ability to transform PST was a trait of bacteria within the Roseobacter clade, with isolated strains being most closely related to Ruegria algicola, Sulfitobacter pontiacus and Antarctobacter heliothermus (Table 3). Roseobacter clade isolates are known to exhibit diverse modes of metabolism with bacterial strains from coastal and oceanic environments reported as able to both utilise organic and inorganic sulphur compounds and

Table 3. Dinoflagellate-associated bacteria capable of transforming paralytic shellfish toxins (PST). U: unknown metabolite(s)

\begin{tabular}{|c|c|c|c|}
\hline $\begin{array}{l}\text { Bacterial } \\
\text { isolate }\end{array}$ & PST transformations & $\begin{array}{l}\text { Nearest neighbour } \\
\text { (GenBank accession no.) }^{a}\end{array}$ & $\begin{array}{l}\text { 16S rRNA sequence } \\
\text { similarity }(\%)^{\mathrm{a}}\end{array}$ \\
\hline \multicolumn{4}{|c|}{$\alpha$-Proteobacteria (Roseobacter clade) } \\
\hline \multirow[t]{3}{*}{ ALUS253_18 } & GTX $5 \rightarrow \mathrm{U}$ & Ruegria algicola (X78313) & 94.5 \\
\hline & & $\begin{array}{l}\text { Isol. 253-13 (AJ294351) isolated from weakly } \\
\text { toxic dinoflagellate culture Alexandrium } \\
\text { lusitanicum NEPCC } 253\end{array}$ & 99.9 \\
\hline & & $\begin{array}{l}\text { Env.PRLISY03 (Y15348) gene clone recovered } \\
\text { from Prorocentrum lima }\end{array}$ & 99.7 \\
\hline \multirow[t]{2}{*}{ SCRIPPS_732 } & GTX $2 / 3 \rightarrow U$ & Sulfitobacter pontiacus (Y13155) & 99.8 \\
\hline & GTX $1 / 4 \rightarrow \operatorname{GTX} 2 / 3+\operatorname{dcGTX} 2$ & & \\
\hline \multirow[t]{2}{*}{ ATAM173a_51 } & GTX $2 / 3 \rightarrow U$ & Antarctobacter heliothermus (Y11552) & 99.6 \\
\hline & & $\begin{array}{l}\text { Isol. } 667-12 \text { (AJ294356) isolated from } \\
\text { Alexandrium affine NEPCC } 667\end{array}$ & 99.9 \\
\hline \multicolumn{4}{|c|}{$\alpha$-Proteobacteria } \\
\hline ALUS253_27 & $\begin{array}{l}\text { GTX } 2 / 3+\operatorname{dcGTX} 2 \rightarrow \text { GTX } 1 / 4 \\
\text { GTX } 1 / 4 \rightarrow \text { GTX } 2 / 3+\text { dcGTX } 2\end{array}$ & Ahrensia kielense (D88524) & 98.9 \\
\hline SCRIPPS_426 & GTX $2 / 3 \rightarrow$ GTX $1 / 4+\mathrm{U}$ & Caulobacter vibroides (AJ227754) & 94.5 \\
\hline
\end{tabular}


transform lignin (Gonzalez et al. 1997, 1999). It is therefore perhaps not surprising that Roseobacter-related strains demonstrate PST-transforming properties. Further, bacteria not within this clade, which demonstrated PST transformations, were associated with Ahrensia kielense and Caulobacter spp. (Hold et al. 2001).

SCRIPPS_426 (Caulobacter sp.) detected in Scrippsiella trochoidea cultures in the exponential growth phase was capable of both SCB toxin production and PST transformation under the conditions described (Tables 2 \& 3). However, this was not a common trait among the bacterial isolates. As SCB activity is not evidence of PST production, additional investigations using alternative growth conditions and testing regimes will be required before conclusions on the catabolism and biosynthesis of PST can be made.

Bacterial isolates ALUS253_27, SCRIPPS_426, SCRIPPS_732 and ATAM173a_51 all appeared to utilise GTX 2 and 3, but in different ways (Table 3, Fig. 2). ALUS253_27 (Ahrensia sp.) and SCRIPPS_426 appeared to transform GTX 2/3 to GTX 1/4 (Fig. 2A,B), suggesting oxidase activity with the conversion of 1 $\mathrm{NH}$ to 1-NOH (Smith et al. 2001). Oshima (1995) reportedly detected oxidase activity in an extract obtained from Alexandrium tamarense, but the transformations of GTX 2/3 to GTX 1/4 have not previously been shown to occur in bacteria. In our chromatograms it appears that dcGTX 2 (ca. 20 min reten- tion time), a minor contaminant of GTX 2/3 standards, was also degraded in cultures of ALUS253_27 and SCRIPPS_732 (Fig. 2A,C). SCRIPPS_732 (Sulfitobacter sp.) also showed rapid utilisation of GTX 2 (100\% after $48 \mathrm{~h}$, data not shown), with only a slight decrease in the amount of GTX 3 observed (Fig. 2C).

The Antarctobacter-related strain ATAM173a_51 and SCRIPPS_426 demonstrated utilisation of GTX 2/3 with concomitant increases in several unidentified compounds (Table 3, Fig. 2B,D). These compounds had retention times of ca. 4, 5, 10 and $18 \mathrm{~min}$ and were observed after $24 \mathrm{~h}$. dcGTX 3 is known to elute prior to dcGTX 2 and this compound may account for the peak observed at 18 min (Fig. 2D). It has previously been suggested that bacterial activity may result in the decarbamoylation of GTX 3 (at N-21) to dcGTX 3 (Smith et al. 2001), while increases in the initial compounds may involve the sulfation of GTX 2/3 giving rise to $\mathrm{C}$ toxins (Smith et al. 2001). In animals and microorganisms, sulfotransferases play an important role in the detoxification of bioactive compounds (Roy 1981) and it is possible that bacterial sulfotransferases have the capacity to sulfate STX analogues, transforming them into less toxic sulfocarbamoyl derivatives.

Following incubation of ALUS253_27, and SCRIPPS_732 with GTX 1 and 4 reductive elimination of the N1 hydroxyl $(\mathrm{OH})$ moiety was observed as demonstrated by the de novo appearance of GTX 2 and 3 (Fig.
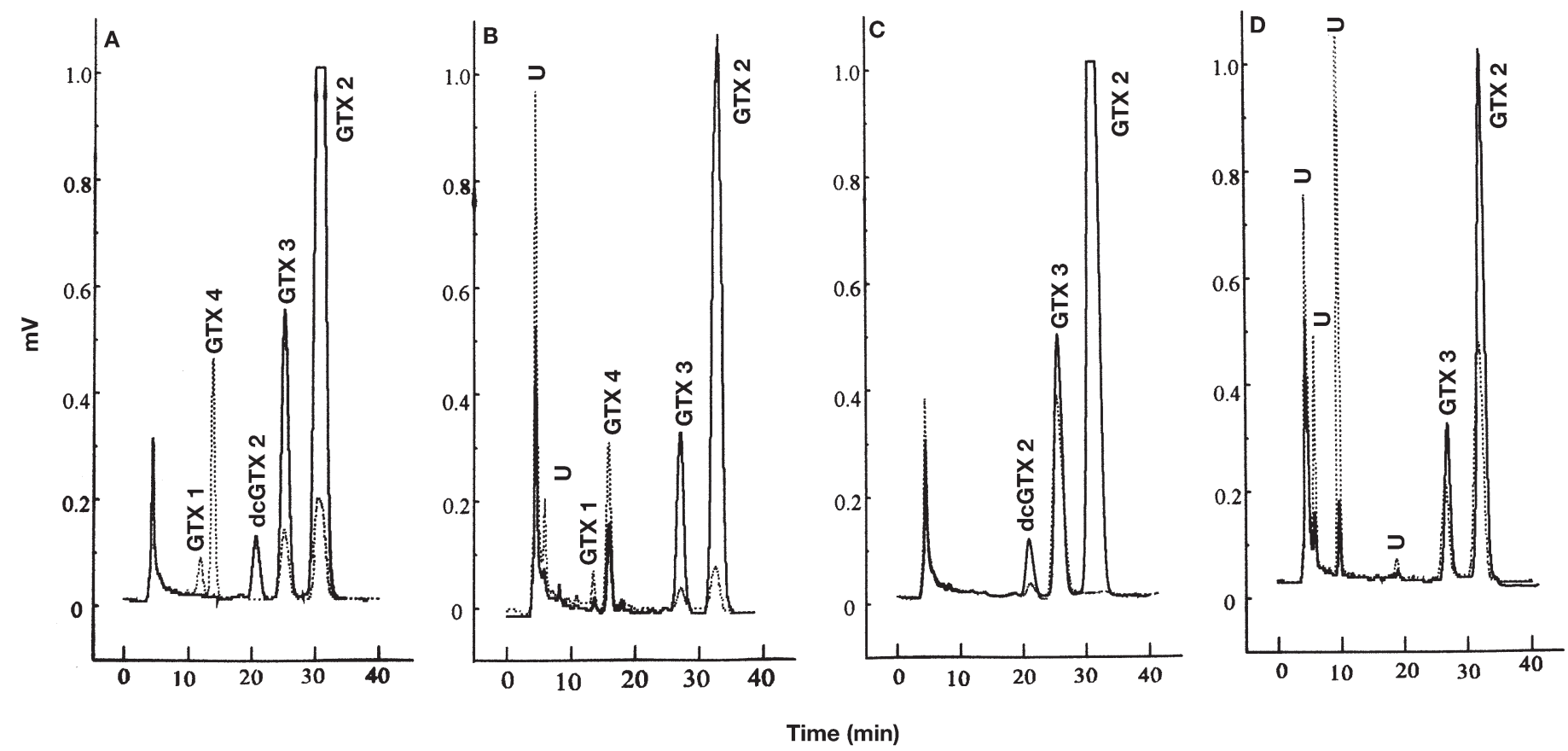

Fig. 2. Chromatogram showing utilisation of GTX2/3 by dinoflagellate-associated bacteria: (A) ALUS253_27, (B) SCRIPPS_426, (C) SCRIPPS_732, (D) ATAM173a_51. Samples shown were taken at $0 \mathrm{~h}$ (black line) and $72 \mathrm{~h}$ (dotted line). U: unknown metabolites 


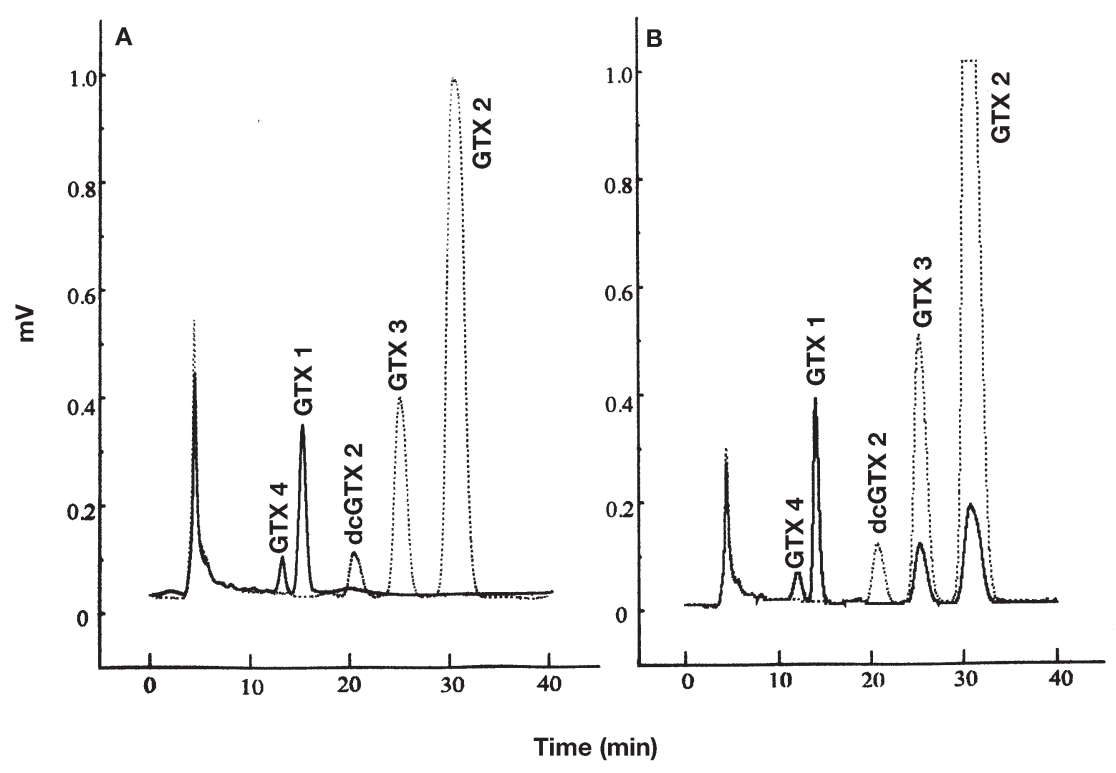

Fig. 3. Chromatogram showing utilisation of GTX1/4 by dinoflagellate-associated bacteria: (A) ALUS253_27, (B) SCRIPPS_732. Samples shown were taken at $0 \mathrm{~h}$ (black line) and $72 \mathrm{~h}$ (dotted line) pounds were observed (data not shown) which remained stable over the $72 \mathrm{~h}$ time period examined (Fig. 4). No other bacterial isolates under these experimental conditions were capable of GTX 5 degradation and this bacterium was not capable of transforming GTX 1/4 or 2/3. However, a similar degradation route has been observed in a bacterial strain isolated from shellfish (Smith et al. 2001).

Almost no data is available on the enzymes involved in PST synthesis; the ability of bacteria to inter-convert these toxin analogues suggests more complicated pathways than have previously been envisaged with intermediates and end products not yet fully elucidated. The presence of bacteria living in close association with dinoflagellates with the ability to transform PST raises questions on the possible effects this may have on dinoflagellate toxicity.

\section{CONCLUSIONS}

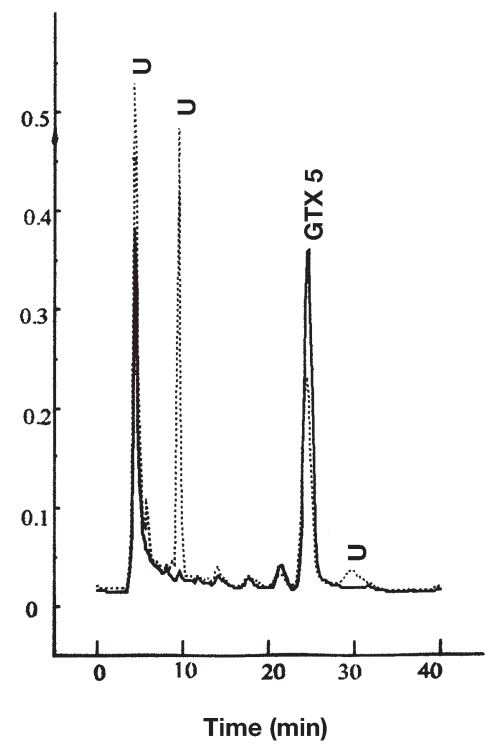

Fig. 4. Chromatogram showing utilisation of GTX 5 by ALUS253_18. Samples shown were taken at $0 \mathrm{~h}$ (black line) and $72 \mathrm{~h}$ (dotted line). U: unknown metabolites

3). This biotransformation mechanism has also been suggested to occur in cultures of bacteria isolated from shellfish (Kotaki et al. 1985a,b, Smith et al. 2001), although natural reductants, such as glutathione and cysteine, are also known to cause this conversion (Oshima 1995).

GTX 5 was partially degraded by ALUS253_18 (Roseobater clade), and after $48 \mathrm{~h}$ increases in unknown com-
A range of bacteria isolated from toxic Alexandrium spp. and non-toxic Scrippsiella trochoidea were capable of SCB activity, while bacteria isolated from a nontoxic A. tamarense strain did not demonstrate this trait. Continued molecular characterisation of SCB/toxigenic bacteria associated with a variety of Alexandrium spp. isolates originating from different locations will, however, be needed to better define any specificity between bacteria and dinoflagellate interactions.

Bacteria isolated from dinoflagellate cultures were also capable of utilising and transforming GTX toxins. However, under these experimental conditions there was little overlap between bacteria that demonstrated SCB activity and those that were able to modify PST, indicating that biosynthesis and catabolism of these compounds may not be related.

Further research into bacterial PST modifications offers the hope of unraveling how multiple PST derivatives are made, with perhaps a clearer picture emerging as to why the large range of numerous analogues with such marked differences in potency are synthesised.

Acknowledgements. This work was supported in part by funds from Fisheries Research Services (United Kingdom) and a European Union grant (FAIR CT96-1558).

\section{LITERATURE CITED}

Alavi M, Miller T, Erlandson K, Schneider R, Belas R (2001) bacterial community associated with Pfiesteria-like 
dinoflagellate cultures. Environ Microbiol 3:380-396

Cembella AD (1998) Ecophysiology and metabolism of paralytic shellfish toxins in marine microalgae. In: Anderson DM, Cembella AD, Hallegraeff GM (eds) Physiological ecology of harmful algal blooms. NATO ASI Series, Vol G41. Springer-Verlag, Berlin, p 381-403

Dantzer WR, Levin RE (1997) Bacterial influence on the production of paralytic shellfish toxins by dinoflagellated algae. J Appl Microbiol 83:464-469

Doucette GJ, Powell CL (1998) Algal-bacterial interactions: can they determine the PSP-related toxicity of dinoflagellates? In: Reguera B, Blanco J, Fernandez ML, Wyatt T (eds) Harmful algae. Xunta de Galicia and Intergovernmental Oceanographic Commission of UNESCO, Grafisant, p 406-409

Doucette GJ, Trick CG (1995) Characterization of bacteria associated with different isolates of Alexandrium tamarense. In: Lassus P, Arzul G, Erad-le Denn E, Gentien P, Marcaillou-le-Baut C (eds) Harmful marine algal blooms. Lavoisier, Paris, p 33-38

Doucette GJ, Kodama M, Franca S, Gallacher S (1998) Bacterial interactions with harmful algal bloom species: bloom ecology, toxigenesis, and cytology. In: Anderson DM, Cembella AD, Hallegraeff GM (eds) Physiological ecology of harmful algal blooms. NATO ASI Series, Vol G41. Springer-Verlag, Berlin, p 619-647

Franca S, Pinto L, Alvito P, Sousa I, Vasconcelos V, Doucette GJ (1996) Studies on prokaryotes associated with PSP producing dinoflagellates. In: Yasumoto $\mathrm{T}$, Oshima $\mathrm{Y}$, Fukuyo Y (eds) Harmul and toxic algal blooms. International Oceanographic Commission of UNESCO, Paris, p 347-350

Franco JM, Fernández-Vila P (1993) Separation of paralytic shellfish toxins by reversed phase high performance liquid chromatography, with post-column reaction and fluorimetric detection. Chromatographia 35:613-620

Gallacher S, Birkbeck TH (1992) A tissue culture assay for direct detection of sodium channel blocking toxins in bacterial culture supernates. FEMS Microbiol Lett 92:101-108

Gallacher S, Smith EA (1999) Bacteria and paralytic shellfish toxins. Protist 150:245-255

Gallacher S, Flynn KJ, Franco JM, Brueggemann EE, Hines HB (1997) Evidence for the production of paralytic shellfish toxins by bacteria associated with Alexandrium spp. (Dinophyta) in culture. Appl Environ Microbiol 63:239-245

Gonzalez JM, Mayer F, Moran MA, Hodson RE, Whitman WB (1997) Sagittula stellata gen. nov, sp. nov, a lignin-transforming bacterium from a coastal environment. Int J Syst Bacteriol 47:773-780

Gonzalez JM, Kiene RP, Moran MA (1999) Transformation of sulfur compounds by an abundant lineage of marine bacteria in the alpha-subclass of the class Proteobacteria. Appl Environ Microbiol 65:3810-3819

Groben R, Doucette GJ, Kopp M, Kodama, M, Amann R, Medlin LK (2000) 16S rRNA targeted probes for the identification of bacterial strains isolated from cultures of the toxic dinoflagellate Alexandrium tamarense. Microb Ecol 39:186-196

Hall S, Strichartz G, Moczydlowski E, Ravindean A, Reichardt PB (1990) The saxitoxins: sources, chemistry and pharmacology. In: Hall S, Stichartz G (eds) Marine toxins: origin, structure, and molecular pharmacology. American Chemical Society, Washington, DC, p 29-65

Hold GL, Smith EA, Rappé MS, Maas EW and 6 others (2001) Characterisation of bacterial communities associated with toxic and non-toxic dinoflagellates: Alexandrium spp. and Scrippsiella trochoidea. FEMS Microbiol Ecol 37 161-173

Johnston MP, Gallacher S, Smith EA, Glover LA (in press) Detection of N-acyl homoserine lactones in marine bacteria associated with production and biotransformation of sodium channel blocking toxins and the microflora of toxin producing phytoplankton. Proc 9th Int Conf on Harmful Algal Blooms

Juntongjin $\mathrm{K}$, Piyakarnchana $\mathrm{T}$, Kogure $\mathrm{K}$, Simidu U, Ohwada, K (1993) Sodium channel blocker-producing bacteria isolated from the Gulf of Thailand. J Mar Biotechnol 1:93-96

Juntongjin K, Piyakarnchana T, Kodama M, Kogure K, Simidu U, Ohwada K (1996) Marine bacteria that produce toxins similar to paralytic shellfish poisons and tetrodotoxins from the sand clam (Asaphis violascens) of the Gulf of Thailand. J Mar Biotechnol 3:268-273

Kodama M (1990) Possible links between bacteria and toxin production in algal blooms. In: Granéli E, Sundström B, Edler L, Anderson DM (eds) Toxic marine phytoplankton. Elsevier, New York, p 52-61

Kodama M, Ogata T, Sato S (1988) Bacterial production of saxitoxin. Agric Biol Chem 52: 1075-1077

Kopp M, Doucette GJ, Kodama M, Gerdts G, Schütt C, Medlin LK (1997) Phylogenetic analysis of selected toxic and non-toxic bacterial strains isolated fromthe toxic dinoflagellate Alexandrium tamarense. FEMS Microbiol Ecol 24:251-257

Kotaki Y (1989) Screening of bacteria which convert gonyautoxin 2, 3 to saxitoxin. Nippon Suisan Gakkaishi 55:1293

Kotaki Y, Oshima Y, Yasumoto T (1985a) Bacterial transformation of paralytic shellfish toxins in coral reef crabs and a marine snail. Bull Jpn Soc Sci Fish 51:1009-1013

Kotaki Y, Oshima Y, Yasumoto T (1985b) Bacterial transformation of paralytic shellfish toxins. In: Anderson DM, White AW, Baden DG (eds) Toxic dinoflagellates. Elsevier Science Publishing, Amsterdam, p 287-292

Lafay B, Ruimy R, Rausch de Traubenberg C, Breittmayer V, Gauthier MJ, Christen, R (1995) Roseobacter algicola sp. nov. a new bacterium isolated from the phycosphere of the toxin-producing dinoflagellate Prorocentrum lima. Int J Syst Bacteriol 45:290-296

Lee MJ, Jeong DY, Kim WS, Kim HD and 6 others (2000) A terodotoxin-producing Vibrio strain, LM-1, from the puffer fish Fugu vermicularis radiatus. Appl Environ Microbiol 66:1698-1701

Levasseur M, Montfort P, Doucette GJ, Michaud S (1996) Preliminary study of bacteria as PSP producers in the Gulf of St. Lawrence, Canada. In Yasumoto T, Oshima Y, Fukuyo Y (eds) Harmful and toxic algal blooms. Intergovernmental Oceanographic Commission of UNESCO, Paris, p 363-366

Matsui, T, Taketsugu S, Kodama K, Ishii A, Yamamori K, Shimizu C (1989) Production of tetrodotoxin by the intestinal bacteria of a puffer fish Takifugu niphobles. Nippon Suisan Gakkaishi 55:2199-2203

Ogata T, Kodama M, Komaru K, Sakomoto S, Sato S, Simidu U (1990) Production of paralytic shellfish toxins by bacteria isolated from toxic dinoflagellates. In: Granéli E, Sundström B, Edler L, Anderson DM (eds) Toxic marine phytoplankton. Elsevier, New York, p 311-315

Oshima Y (1995) Chemical and enzymatic transformations of paralytic shellfish toxins in marine organisms. In: Lassus $P$, Arzul G, Gentien P, Marcaillou C (eds) Harmful marine algal blooms. Lavoisier Publishers, Paris, p 475-480

Prokic I, Brummer F, Brigge T, Gortz HD, Gerdts G, Schutt C, Elbrachter M, Muller WEG (1998) Bacteria of the genus 
Roseobacter associated with the toxic dinoflagellate Prorocentrum lima. Protist 149:347-357

Rausch de Traubenberg (1993) Interactions entre un dinoflagellé et microflore bactérienne associée: rôle des bactéries dans la toxicité de Procentrum lima Ehhrenberg (Dodge). $\mathrm{PhD}$ thesis, Université de Nantes

Roy AB (1981) Sulfotransferases. In: Mulder GJ (ed) Sulfation of drugs and related compounds. CRC press, Boca Raton, FL, p 131-185

Shimizu Y (1993) Microbial metabolites. Chem Rev 93: $1685-1689$

Editorial responsibility: Robert Sanders,

Philadelphia, Pennsylvania, USA
Silva ES (1982) Relationship between dinoflagellates and intracellular bacteria. Mar Algae Pharmac Sci 2: 269-288

Smith EA, Grant F, Ferguson CMJ, Gallacher S (2001) Biotransformations of paralytic shellfish toxins by bacteria isolated from bivalve molluscs. Appl Environ Microbiol 67:2345-2353

Vásquez M, Gruttner C, Gallacher S, Moore ERB (2001) Detection and characterisation of toxigenic bacteria associated with Alexandrium catenella and Aulacomya ater contaminated with PSP. J Shellfish Res 20:1245-1249

Submitted: February 6, 2002; Accepted: June 27, 2002

Proofs received from author(s): August 19, 2002 